University of Nebraska - Lincoln

DigitalCommons@University of Nebraska - Lincoln

\title{
4 Humans, Climate, and Plants: the Migration of Crested Wheatgrass and Smooth Bromegrass to the Great Plains of North America
}

Kenneth P. Vogel

University of Nebraska-Lincoln, kvogel1@unl.edu

Vogel, Kenneth P., "4 Humans, Climate, and Plants: the Migration of Crested Wheatgrass and Smooth Bromegrass to the Great Plains of North America" (2004). Publications from USDA-ARS / UNL Faculty. 2092.

https://digitalcommons.unl.edu/usdaarsfacpub/2092

This Article is brought to you for free and open access by the U.S. Department of Agriculture: Agricultural Research Service, Lincoln, Nebraska at DigitalCommons@University of Nebraska - Lincoln. It has been accepted for inclusion in Publications from USDA-ARS / UNL Faculty by an authorized administrator of DigitalCommons@University of Nebraska - Lincoln. 


\title{
4 Humans, Climate, and Plants: the Migration of Crested Wheatgrass and Smooth Bromegrass to the Great Plains of North America
}

\author{
Kenneth P. Vogel \\ Research Geneticist, USDA-ARS, 344 Keim Hall, Univ. of Nebraska, Lincoln, \\ Nebraska 68583, USA, E-mail kpv@unlserve.unl.edu
}

\subsection{Abstract}

The cultivation practices that were used in Europe and the eastern half of North America were utilized in the initial settlement of the Great Plains. Unfamiliarity with the climate of the Great Plains and Midwest and insufficient knowledge and technology to adapt crop production systems to the soils and climate lead to a major agriculture disaster which resulted in millions of hectares of land that needed to be re-seeded to grasses. Unrestricted grazing on public lands in the intermountain west resulted in severe rangeland degradation. Lack of knowledge and technology for using native plants and some specific characteristics of native plants that made them difficult to use resulted in the use of crested wheatgrasses and smooth bromegrass which had characteristics that met specific revegetation and production requirements. Crested wheatgrass and smooth bromegrass plant materials were from regions that were climatic analogs of the Great Plains and were adapted. These two grasses literally preserved the remaining top soil on millions of hectares of land. In the subsequent half-century, agronomist, geneticists, and rangeland scientists have learned how to establish and manage native grasses such as switchgrass (Panicum virgatum L.), big bluestem (Andropogon gerardii Vitman), indiangrass [Sorghastrum nutans (L.) Nash] and others so they are now available for use in revegetation. Although native grasses are available for use in the Great Plains and the Midwest of North America, crested wheatgrass and smooth bromegrass are now naturalized North American species and will continue to be vital to the economy of the USA and Canada. Their forage production patterns fits gaps in the forage production cycle for ruminant livestock that cannot be adequately met by native species in regions where bromegrass and crested wheatgrasses are well adapted. 


\subsection{The Plants}

Humans throughout history have migrated to new areas and taken their food plants and animals with them (Harlan 1975; Diamond 1997). They also have utilized plants indigenous to the area into which they have migrated. The Great Plains and Midwest of North America were vast grasslands prior to the migration and settlement by people of largely northern European origin. One hundred and fifty years later, significant land areas have been converted to cultivation and are in crop production. Millions of hectares of land also have been planted to crested wheatgrass (Agropyron spp.) and smooth bromegrass (Bromus inermis Leyss.) which are nonnative forage and pasture species. The purpose of this report is to describe the interactions of humans, plants, and climate that resulted in the migration and utilization of Eurasian grasses on millions of hectares of North American grasslands. The use and status of these species in North America continue to evolve as humans, plants, and their environment interact.

The genus Agropyron has contained many of the species of the perennial Triticeae but in current taxonomy it is restricted to species of the crested wheatgrass complex which is a polyploid series based on the ' $\mathrm{P}$ ' genome (Asay and Jensen 1996). The genus consists of a series of diploid $(2 n=14)$, tetraploid $(2 n=28)$, and hexaploid $(2 \mathrm{n}=42)$ species. The cultivated type species are $A$. cristatum or Fairway crested wheatgrass and $A$. desertorum (Fisch. ex Link) Schultes or Standard crested wheatgrass. The Standard type has been the most widely used in the USA; the Fairway type has been used in Canada in addition to the Standard type. Crested wheatgrasses are persistent, long-lived perennial bunchgrasses adapted to temperate sites receiving 200 to $450 \mathrm{~mm}$ of annual precipitation. The inflorescence is a spike, and culms range in height from 15 to more than $100 \mathrm{~cm}$. Crested wheatgrasses are native to the steppe region of European Russia and southwestern Siberia (Asay and Jensen 1996). Crested wheatgrasses were apparently first cultivated in the Volga district east of Saratov (Asay and Jensen 1996). Crested wheatgrasses have excellent seed production and the seed is easy to harvest, clean, and plant. They have excellent seedling vigor, drought and cold resistance, and can tolerate heavy grazing. In areas where they are adapted, they typically produce equivalent or greater forage yields and livestock carrying capacity than native rangelands.

Smooth bromegrass is a leafy, tall-growing, sod-forming perennial cool-season grass adapted to temperate regions (Vogel et al. 1996). The commonly grown form of smooth bromegrass is an autoallooctaploid with a chromosome number of $2 n=56$ while the lesser used tetraploid $(2 n=28)$ is an allotetraploid. The flowering culms are 50 to $100 \mathrm{~cm}$ in height. The inflorescence is a panicle that is erect and 7 to $20 \mathrm{~cm}$ long with whorled branches, and becomes contracted and purplish brown at maturity (Vogel et al. 1996). It is of Eurasian origin and it is a polymorphic species which can be divided into several subspecies or ecotypes that are related to their origin (Tsvelev 1984). Zerebina $(1931,1933,1938)$, whose research was subsequently summarized by Knowles and White (1949), recognized two main ecological-geographical groups: the "meadow" group or northern climatype, and 
the "steppe" group or southern climatype. Descriptions of these groups correspond to the northern and southern types of smooth bromegrass later recognized in North America (Newell and Keim 1943). The meadow types were found from Murmansk in the north to the Caucasus in the south, although south of the central Chernozem region they were found only in valleys and moist habitats. The steppe type was found with the meadow type in the central Chernozem region and was the principal ecotype in the dry steppe areas of the mid and lower Volga districts, Kazakhstan, the northern Caucasus, the eastern Ukraine, and the southern Altai regions of the former USSR. Smooth bromegrass is widely adapted because of the ecotypic variation that exists in the species in its native range. It is similar to the crested wheatgrasses in that it is an excellent seed producer, seed is easy to harvest and clean, and it has excellent seedling vigor and establishes rapidly. It can tolerate mismanagement and heavy grazing pressure and is very productive if well managed. It is not as drought tolerant as crested wheatgrass but has better drought tolerance than other mesic cool-season grasses such as perennial ryegrass (Lolium perenne L.), timothy (Phleum pratense L.), or cocksfoot (Dactylis glomerata L.; Vogel et al. 1996). It produces significantly more forage than crested wheatgrasses in regions where annual precipitation exceeds $500 \mathrm{~mm}$.

\subsection{Settlement, Agriculture and War}

The Great Plains of the United States were settled by people of largely northern European origin (Morison 1965). The Midwest was settled from about 1820 to 1865 (Morison 1965). The conclusion of the American Civil War in 1865 marked the beginning of the primarily settlement period of the Great Plains which ended about 1900 (Morison 1965). When the prairies and grasslands were first settled, there were abundant grasslands for farmers' cattle and horses. Farmers plowed areas of their farms for grain crop production, primarily maize, oats, and wheat, but retained grasslands for use by their livestock. Although the crops that the settlers brought with them were adequately adapted to the Great Plains, the production systems that the settlers brought with them were not. These systems involved yearly plowing and intensive cultivation for weed control. This left the soil bare and subject to wind and water erosion.

In the prairies and plains of these sections of North America, most of the grasslands contained grasses which had the $\mathrm{C}_{4}$ photosynthesis system. These warmseason grasses did not have the production patterns of cool-season or $\mathrm{C}_{3}$ grasses to which the settlers were accustomed (Moser and Vogel 1995). Warm-season grasses start growing 4 to 6 weeks later in the spring than cool-season grasses and go dormant as temperatures drop in the autumn. They require different management than cool-season grasses. As a result, the native pastures were often mismanaged and overgrazed and gradually were reduced in productivity. Farmers wanted new pasture plants that could produce more forage than the native grassland and which would provide grazing in spring and autumn. Plant explorers were 
employed by the United States Department of Agriculture (USDA) to collect plant material for use in these and other regions of the United States.

The demand for grain crops including wheat before and after World War I resulted in additional millions of hectares of land being plowed during the period 1905 to 1920 and used for grain production (Dillman 1946). This included land in marginal crop production areas that had not been converted to grain crop agriculture in the initial settlement period. Prices for grain crops were high and climatic conditions were favorable for grain crop production which encouraged farmers to convert grasslands to cultivated croplands.

\subsection{Disaster - The Drought of the 1930s}

In the 1930s or the "Dust Bowl" era, a major drought affected large parts of North America resulting in massive soil erosion problems, particularly on lands that were only marginally suited for crop production. In seven of the ten years between 1928 and 1937, average annual precipitation was below the long-term average (Lorenz 1986). The drought resulted in severe wind erosion and soil drift onto cropland, and loss of plants on overgrazed grasslands. By the end of the 1930s millions of hectares of land in the former prairie and plains states of the USA and Canadian provinces needed to be reseeded to grasslands to preserve the soil and the ecosystems. This drought resulted in the realization that considerable land had been plowed that needed to be rapidly converted into grasslands, and severely damaged grasslands needed to be restored by reseeding.

There were problems with using native species. Native grasslands had been abundant and common and as a result almost no information was available on seed production and establishment of native species. Many of the native species have seed with chaffy appendages which made harvesting, cleaning, and planting difficult and only limited amounts of seed could be obtained from native harvests (Cornelius 1950; Masters et al. 1993). Research was initiated on native grasses beginning in the mid-1930s but a more immediate solution to the revegetation problem was needed. The introduced species that survived the drought, had good seed yields, and that could be readily established were smooth bromegrass and the crested wheatgrasses. Grasses such as cocksfoot and timothy often did not survive the drought in the midwestern USA. After their introduction in the late 1880s, experiment stations in both the USA and Canada had evaluated the available germplasm and made selections. Research had been conducted on seed production, establishment, forage production, and grazing management. By the end of the 1930s, plant materials and the associated technology were available for a rapid increase in use of the species (Dillman 1946; Lorenz 1986; Rogler and Lorenz 1983; Newell 1973; Vogel et al. 1996). 


\subsection{Crested Wheatgrass Story}

Crested wheatgrasses were first introduced into North America in 1892 by N.E. Hansen of the South Dakota Experiment Station (Dillman 1946; Rogler and Lorenz 1983; Lorenz 1986). Hansen was born in Denmark in 1866 and immigrated with his family at the age of seven to the USA (Taylor 1941). His family lived in Iowa and he attended Iowa State College (now Iowa State University) where he received B.S. and M.S. degrees. Even as a student, he was interested in the history and migration of plants and their improvement (Taylor 1941). In 1895, he went to South Dakota State College at Brookings, SD, as Professor of Horticulture. While there, he was contracted by USDA to do plant exploration and collection because of his knowledge of plants and languages (Taylor 1941). He was the first official plant explorer for the USDA. In his first collection trip, which was in 1897-1898, he collected five railroad cars of several hundred kinds of grains, grasses, and plants from Russia, Turkestan, China, Siberia, and Transcaucasus. The material, which included seed of crested wheatgrass from the eastern Volga region and Siberia, was shipped to USDA, Division of Seed and Plant Introduction, Washington, D.C., for distribution to experiment stations. On this trip, he also obtained 12 tons of bromegrass seed from the Volga region of Russia. This seed was distributed to several experiment stations but no permanent plantings or seed increases of crested wheatgrasses were apparently made (Dillman 1946; Lorenz 1986; Asay and Jensen 1996).

N.E. Hansen received a second importation of crested wheatgrass in 1906 from the Valuiki Experiment Station in Russia which consisted of five $A$. desertorum seedlots (PIs 19537-19541) and one $A$. cristatum seedlot (PI 19536). Seed was distributed to 15 experiment stations (Dillman 1946). The first known research planting of these accessions was at the Belle Fouce, SD, research station in 1908. A.C. Dillman was a USDA agronomist at the station and maintained plantings of the crested wheatgrass from 1908 to 1915 . He harvested and supplied seed to other stations including what is now the Agricultural Research Service (ARS), USDA Laboratory at Mandan, ND (Dillman 1946; Rogler and Lorenz 1983; Lorenz 1986). Plantings made in 1915 at Mandan were the foundation from which the initial cultivar released in the United States was developed. Over $100 \mathrm{~kg}$ of seeded was distributed to experiment stations and farms in the Dakotas, Montana, and Wyoming from 1920 to 1923 (Dillman 1946). Before the release of the first cultivar, over $1800 \mathrm{~kg}$ of seed of four of the better accessions was distributed to farmers for testing (Dillman 1946). The first pasture trial was established in 1923 at the Ardmore, SD, field station and performance trials with dairy cattle were successful (Lorenz 1986). The first grazing trial with beef cattle was established at Mandan, ND, in 1932. The pasture was still in production in 1983 (Rogler and Lorenz 1983; Lorenz 1986). The first farm planting was in Montana. Direct increases in the available accessions were used in the initial plantings of the crested wheatgrasses. The first commercial seed field was started by a farmer near Dickenson, ND, in 1926 and first seed was offered for sale in 1928. This farmer had over 80 ha in seed production when the demand for seed came in 1933 as a result 
of government revegetation programs (Lorenz 1986. In the 25-period between 1906 when N.E. Hansen received his second shipment of crested wheatgrass germplasm and 1933, agronomists at several experiment stations developed the basic agronomic information that was needed for it to become a widely utilized grass. The standard crested wheatgrass cultivar "Nordan" was released by the Mandan, ND, station in 1953 and was the most widely used cultivar in the United States for many years (Asay and Jensen 1996).

In Canada, crested wheatgrass research began in 1916 at Saskatoon, Saskatchewan, by L.E. Kirk who at that time was a graduate assistant (Dillman 1946). Seed was obtained from the USA and included PI 19536 and PI 19540 which were among those received by N.E. Hansen in 1906. Other seed lots were sent to Saskatoon at a later date from Mandan, ND. The first crested wheatgrass cultivar, "Fairway" was a mass selection of fine leafy plants from PI 19536 which were harvested in 1925 (Dillman 1946). Breeding work has continued on crested wheatgrass at several research stations in both the United States and Canada and improved cultivars and management practices are periodically documented and released (Asay and Jensen 1996).

\subsection{Bromegrass Story}

Smooth bromegrass was introduced into the USA and Canada in the 1880s (Newell 1973; Vogel et al. 1996). The first introduction was by the California Experiment Station in 1884 which distributed seed to other experiment stations (Newell 1973). Major introductions were from central Europe including Hungary, northern Germany, and the Russian collections of N.E. Hansen (Taylor 1941; Newell 1973). By the late 1890s bromegrass was being grown in the Midwest and Great Plains of the USA and Canada. Bromegrass identified as "Hungarian" bromegrass was sown on the University of Nebraska Experiment Station farm at Lincoln, NE, in 1897 in a small field (Lyon 1899). Seed and forage yields were determined. In 1898 , a 6.5 -ha pasture was established that was used in grazing trials by cattle and horses. In his summary, Lyon (1899) noted that its advantages over the native prairie grasses was that it became green fully a month earlier in the spring and remained green later into the autumn. He indicated that it was not as good for butter and milk production as bluegrass (Poa pratensis L.) and white clover (Trifolium repens L.) from dairy cattle but that it was safe and widely adaptable. Similar results were being obtained from other experiment stations (Waldron and Porter 1919). The initial spread and distribution of smooth bromegrass in North America were based on the simple increase and distribution of the introduced strains from experiment stations to farmers. The first recorded breeding work on smooth bromegrass was conducted in the early 1900 s by two Kansas farmers, the Achenbach brothers, who did mass selection on one of their best bromegrass fields to develop "Achenbach" bromegrass (Vogel et al. 1996). Initial breeding work by several experiment stations was initiated between 1910 and 1920 but did not lead to the development of any cultivars and was not re-initiated until the drought of 
the 1930s stimulated breeding work at several locations. During the 30 -year period from the late 1890 s to the early 1930 s, agronomic information was obtained on the management of smooth bromegrass at locations throughout the prairie regions of the United States and Canada.

Breeding programs for bromegrass were initiated at several experiment stations beginning in the mid-1930s to develop grasses for reseeding the lands ravaged by the drought. Typically, the breeders worked on multiple species. The breeding programs used available germplasm resources, primarily domestic germplasm sources such as old plantings that had been in existence for sufficient periods of time to have become naturalized (Vogel et al. 1996). The evaluation work documented the existence of "southern" and "northern" strains of smooth bromegrass (Newell and Keim 1943; Knowles and White 1949). The southern types, which were believed to trace from the Hungarian introductions, were the best adapted to the Central Great Plains and the southern part of the Corn Belt, while the northern strains were best adapted to the Northern Plains, the upper Midwest and northeastern states, and to the adjacent provinces of Canada, and traced to some of the accessions originally collected by Hansen in 1897 and to other accessions from northern Europe (Vogel et al. 1996). The first series of cultivars did not involve any formal breeding work other than selection among existing ecotypes or strains. For example, seed from several old plantings in Nebraska proved superior to other germplasm sources and were traced to a common origin. These fields were certified and were the source of the cultivar "Lincoln" which is still a widely used (Vogel et al. 1996; Casler et al. 2000). Bromegrass breeding and management research have been continued to the present at several locations in both the USA and Canada.

\subsection{The Success Story}

The early evaluation and management work enabled seed production of crested wheatgrass to be rapidly expanded. Information on establishment practices including planting dates enabled land to be rapidly and efficiently re-vegetated during the 1940s and 1950s. Because it was often the only adapted grass for which seed was available in quantity for its area of adaptation, it was often seeded in monocultures. Crested wheatgrass salvaged vast areas of deteriorated rangelands and abandoned cropland in the central and northern plains of North America that were severely damaged during the "dust bowl" period of the 1930s (Rogler and Lorenz 1983; Lorenz 1986). Many of these plantings remain and are still productive. Crested wheatgrass also has become the most important domestic grass in the arid intermountain West of the United States. In the intermountain West, excessive and unregulated livestock grazing by sheep and cattle in the late $1800 \mathrm{~s}$ and early 1900 s led to severe rangeland degradation and to a change in the vegetation community (Harrison et al. 2003). By 1932, the vegetation in the some areas of the Great Basin region had changed from 49 to $81 \%$ perennial grass and $10 \%$ sagebrush to mainly sagebrush ground cover (Harrison et al. 2003). Re-vegetation 
was needed to restore these degraded rangelands and to combat invading noxious weeds. In this region, many of the native cool-season plants do not tolerate heavy grazing (Asay and Jensen 1996). Crested wheatgrasses were found to be well adapted in trials that began in the late 1930s (Harrison et al. 2003). The annual poisonous forb, halogeton became a serious threat to livestock on intermountain rangelands during the $1940 \mathrm{~s}$. Crested wheatgrass proved to be an effective biological suppressor of this weed (Mathews 1986; Young and Evans 1986). Agricultural statistics are not available on the land area that has been seeded and is currently vegetated by crested wheatgrasses, but it is estimated that 5.1 million and 800,000 ha had been seeded to crested wheatgrass in the USA and Canada, respectively, by the early 1980s (Rogler and Lorenz 1983; Asay and Jensen 1996). It is primarily used north of $40^{\circ} \mathrm{N}$ lat. and west of $100^{\circ} \mathrm{W}$ long. It is used in lower latitudes at higher elevations in the intermountain area. Pasture and rangeland planted to crested wheatgrass are primarily used for grazing.

Similar to the crested wheatgrass, the early work on smooth bromegrass enabled it to be rapidly increased and utilized to restore degraded lands following the 1930 s drought. For example, by 1945 , almost 500,000 ha had been seeded in the state of Nebraska (Frolik 1945). It was and continues to be primarily utilized in North America in regions north of $40^{\circ} \mathrm{N}$ lat. and east of $100^{\circ} \mathrm{W}$ long. that have 500 $\mathrm{mm}$ or more annual precipitation, or in areas that have similar temperature ranges because of elevation (Vogel et al. 1996). It is estimated that the Midwest and eastern states of the USA and the adjacent provinces of Canada each have over 500,000 ha of smooth bromegrass. The principal use of smooth bromegrass is as a cool-season pasture grass in this region (Vogel et al. 1996). It is the principal component of these pastures, although legumes, particularly alfalfa (Medicago sativa L.), are usually included in the plantings. In addition, it remains the most important grass for conservation purposes in this region where it is used on roadsides, grass waterways, and field borders for erosion control.

\subsection{The Alien Problem}

Crested wheatgrass and smooth bromegrass are not regarded favorably by everyone even though they saved millions of hectares of land from severe erosion and remain economically important grasses in both pasture and rangelands (Lesica and DeLuca 1996; Christian and Wilson 1999). Most of the criticism is based on the fact that they are not native species and that pure stands of the species lack biological diversity. Native species are considered by many ecologists to be more desirable than the introduced grasses. Both crested wheatgrass and smooth bromegrass can be found on invasive species lists of environmental organizations on the internet (http://www.americanlands.org; http://tncweeds.ucdavis.edu; verified 29 September 2003). Some of these groups also list tall fescue (Festuca arundinaceae Schreb.) and white and yellow sweet clover (Melilotus alba Medikus and $M$. officinalis Lam., respectively) as invasive plants. Smooth bromegrass and crested wheatgrass are viewed as invaders of native rangeland and remnant prairie sites. 
Personal observation and published reports (Blankenpoor and May 1999; Broersma et al. 2000) indicate that neither grasses invades grasslands that are well managed and in good condition. Bromegrass will invade disturbed areas and poorly managed native grasslands especially in the tallgrass prairie ecoregion. Crested wheatgrass is very non-invasive and usually does not spread from where it is planted. The soil quality of long-term crested wheatgrass fields or range sites has been reported to be below that in adjacent, unplowed prairie (Lesica and DeLuca 1996; Christian and Wilson 1999). The fact that the sites seeded to crested wheatgrass had been plowed and eroded before they were seeded to crested wheatgrass is often ignored or remains a confounding factor in research reports. Other reports indicate that grazed crested wheatgrass and native prairies produce similar amounts of root biomass (Krzic et al. 2000).

Crested wheatgrass will need to be used in the intermountain West of the USA and Canada for noxious weed control. Invasion of rangelands by the annual bromegrass, Bromus tectorum L., or cheatgrass have created severe problems including rangeland fires that in the state of Utah alone burn almost 60,000 hectares annually (Harrison et al. 2003). Plants that can be used to control cheatgrass and other noxious weeds are needed, although vigorous cultivars such as Hycrest can effectively compete against noxious weeds such as cheatgrass and halogeton. A rapidly spreading noxious weed, spotted knapweed (Centurea maculosa auct. non Lam.), has been shown recently to release a phytotoxin from its roots that triggers the death of the root system of grasses native to the intermountain region in the western USA (Bais et al. 2003). European grasses were more resistant to the toxin and will likely be needed as part of the control strategy for this noxious weed.

Pumpelly's brome (Bromus inermis Leyss. ssp. pumpellianus (Scribn.) Wagnon) is a perennial bromegrass that is native to Alaska and the western and northern intermountain areas of North America. Based on genetic studies which have demonstrated that it has the same nuclear and cytoplasmic genomes as smooth bromegrass with which it is fully fertile, it has been reclassified as a subspecies of smooth bromegrass (Armstrong 1982; Pillay and Hilu 1990; Vogel et al. 1996). Pumpelly's brome probably migrated during periods when Asia and Northern America were connected via a land bridge between Alaska and Siberia, and because of isolation developed small differences in morphology while retaining the genome intact. It can be argued that smooth bromegrass should be regarded as a native of North America because its genome was already present in Pumpelly's bromegrass.

\subsection{Conclusions}

The crested wheatgrass and smooth bromegrass are now naturalized species of North America. Their use in re-vegetation and conservation saved the topsoil on millions of hectares of land. They will continue to be used in production agriculture and in restoring degraded rangelands that have been invaded by noxious weeds. 


\subsection{References}

Armstrong KC (1982) Hybrids between the tetraploid and octaploid cytotypes of Bromus inermis. Can J Bot 60:476-482

Asay KH, Jensen KB (1996) Wheatgrasses. In: Moser LE, Buxton D, Casler MD (eds) Cool-season forage grasses. Agron Monogr ASA, CSSA, SSSA, Madison, WI, pp 691724

Bais HP, Vepachedu R, Gilroy S, Callaway RM, Vivanco JM (2003) Allopathy and exotic plant invasion: from molecules and genes to species interactions. Science 301:13771380

Blankenspoor GW, May JK (1996) Alien smooth brome (Bromus inermis Leyss) in a tallgrass prairie remnant: seed bank, seedling establishment, and growth dynamics. Natural Areas J 16:289-294

Broersma, Krzic M, Thompson DJ, Romke AA (2000) Soil and vegetation of ungrazed crested wheatgrass and native rangelands. Can J Soil Sci 80:411-417

Christian JM, Wilson SD (1999) Long-term ecosystem impacts of an introduced grass in the northern Great Plains. Ecology 80:2397-2407

Casler MD, Vogel KP, Balasko JA, Berdahl JD, Miller DA, Hansen JL, Fritz JO (2000) Genetic progress from 50 years of smooth bromegrass breeding. Crop Sci 40:13-22

Cornelius DR (1950) Seed production of native grasses under cultivation in eastern Kansas. Ecol Monogr 20:1-29

Diamond J (1997) Guns, germs, and steel. Norton, New York, NY

Dillman AC (1946) The beginnings of crested wheatgrass in North America. J Am Soc Agron 38:237-250

Frolik EF (1945) 1,000,000 acres of bromegrass. Nebraska Farmer 87:1-40

Harlan JR (1975) Crops and man. American Society of Agronomy and Crop Science Society of America, Madison, WI

Harrison RD, Chatterton NJ, McArthur ED, Ogle D, Asay KH, Waldron BL (2003) Range plant development in Utah: a historical view. Rangelands 25:13-19

Knowles RP, White WJ (1949) The performance of southern strains of bromegrass in western Canada. Sci Agric 29:437-50

Krzic M, Broersma K, Thomson DJ, Bomke AA (2000) Soil properties and species diversity of grazed crested wheatgrass and native rangelands. J Range Manage 53:353-358

Lesica P, DeLuca TH (1996) Long-term harmful effects of crested wheatgrass on Great Plains grassland ecosystems. J Soil Water Conserv 51:408-409

Lorenz RJ (1986) Introduction and early use of crested wheatgrass in the Northern Great Plains. In Johnson KL (ed) Crested wheatgrass: Its values, problems, and myths. Symp Proc Utah State Univ, Logan, UT, 3-7 Oct 1983. Utah State Univ., Logan, UT, pp 9-20 Lyon TL (1899) Hungarian brome grass. Nebraska Agricul Exp Stn Bull 61 (XII):35-63

Masters RA, Mitchell RB, Vogel KP, Waller SS (1993) Influence of improvement practices on big bluestem and indiangrass seed production in tallgrass prairies. J Range Manage 46:183-187

Mathews WL (1986) Early use of crested wheatgrass seedings in halogeton control. In Johnson KL (ed) Crested wheatgrass: its values, problems, and myths. Symp Proc Utah State Univ, Logan, UT, 3-7 Oct 1983. Utah State Univ, Logan, UT, pp 27-28

Morison SE (1965) The Oxford history of the American people. Oxford Press, New York 
Moser LE, Vogel KP (1995) Switchgrass, big bluestem, and indiangrass. In: Barnes RF, Miller DA, Nelson CJ (eds) Forages, vol I, 5th edn. An introduction to grassland agriculture. Iowa State Univ Press, Ames, IA, pp 409-420

Newell LC (1973) Smooth bromegrass. In: Heath ME, Metcalfe DS, Barnes RF (eds) Forages. The Science of grassland agriculture. Iowa State University Press, Ames, IA, pp 254-262

Newell LC, Keim FD (1943) Field performance of bromegrass strains from different seed sources. J Am Soc Agron 35:420-434

Pillay M, Hilu KW (1990) Chloroplast DNA variation in diploid and polyploidy species of Bromus (Poaceae) subgenera Festucaria and Ceratchloa. Theor Appl Genet 80:326-332

Rogler GA, Lorenz RJ (1983) Crested wheatgrass - early history in the United States. J Range Manage 36:91-93

Taylor HJ (1941) To plant the prairies and the plains. The life and work of Niels Ebbesen Hansen. BIOS XII:1-72

Tsvelev NN (1984) Grasses of the Soviet Union, part I. Balkema, Rotterdam. (Russian translations series)

Vogel KP, Moore KJ, Moser LW (1996) Bromegrasses. In: Moser LE, Buxton D, Casler MD (eds) Cool-season forage grasses. Agronomy monograph ASA, CSSA, SSSA, Madison, WI, pp 535-567

Waldron LR, Porter WR (1919) Brome-grass, slender wheat-grass and timothy. North Dakota Agric Exp Stn Circ 24:1-8

Young JA, Evans RA (1986) History of crested wheatgrass in the Intermountain Area. In: Johnson KL (ed) Crested wheatgrass: its values, problems, and myths. Symp Proc Utah State Univ, Logan, UT, 3-7 Oct 1983, Utah State Univ, Logan, UT, pp 21-25

Zerebina ZN (1931) Botanical-agronomical studies of awnless brome grass (Bromus inermis Leyss.). Bull Appl Bot Genet Plant Breed 25:201-352

Zerebina ZN (1933) Awnless brome grass. Rastenievodstvo USSR 1:507-518

Zerebina ZN (1938) Brome grass. Rukovod Approb Seljskohoz Kuljt 4:112-123 